\title{
Haemodynamic consequences of changing potassium concentrations in haemodialysis fluids
}

\author{
Luca Gabutti ${ }^{1} 2^{*}$, Igor Salvadé ${ }^{2}$, Barbara Lucchini ${ }^{2}$, Davide Soldini ${ }^{1}$ and Michel Burnier ${ }^{3}$
}

\begin{abstract}
Background: A rapid decrease of serum potassium concentrations during haemodialysis produces a significant increase in blood pressure parameters at the end of the session, even if effects on intra-dialysis pressure are not seen. Paradoxically, in animal models potassium is a vasodilator and decreases myocardial contractility. The purpose of this trial is to study the precise haemodynamic consequences induced by acute changes in potassium concentration during haemodialysis.

Methods: In 24 patients, 288 dialysis sessions, using a randomised single blind crossover design, we compared six dialysate sequences with different potassium profiles. The dialysis sessions were divided into 3 tertiles, casually modulating potassium concentration in the dialysate between the value normally used $\mathrm{K}$ and the two cut-off points $\mathrm{K}+1$ and $\mathrm{K}-1 \mathrm{mmol} / \mathrm{l}$. Haemodynamics were evaluated in a non-invasive manner using a finger beat-to-beat monitor.

Results: Comparing $\mathrm{K}-1$ and $\mathrm{K}+1$, differences were found within the tertiles regarding systolic $(+5.3,+6.6,+2.3$ $\mathrm{mmHg}, \mathrm{p}<0.05,<0.05, \mathrm{~ns})$ and mean blood pressure $(+4.3,+6.4,-0.5 \mathrm{mmHg}, \mathrm{p}<0.01,<0.01, \mathrm{~ns})$, as well as peripheral resistance $\left(+212,+253,-4\right.$ dyne.sec. $\left.\mathrm{cm}^{-5}, \mathrm{p}<0.05,<0.05, \mathrm{~ns}\right)$. The stroke volume showed a nonstatistically-significant inverse trend $(-3.1,-5.2,-0.2 \mathrm{ml})$. 18 hypotension episodes were recorded during the course of the study. $72 \%$ with $\mathrm{K}-1,11 \%$ with $\mathrm{K}$ and $17 \%$ with $\mathrm{K}+1$ ( $\mathrm{p}<0.01$ for comparison $\mathrm{K}-1$ vs. $\mathrm{K}$ and $\mathrm{K}-1$ vs. $\mathrm{K}+1$ ).

Conclusions: A rapid decrease in the concentration of serum potassium during the initial stage of the dialysisobtained by reducing the concentration of potassium in the dialysate-translated into a decrease of systolic and mean blood pressure mediated by a decrease in peripheral resistance. The risk of intra-dialysis hypotension inversely correlates to the potassium concentration in the dialysate.
\end{abstract}

Trial Registration Number: NCT01224314

Keywords: Haemodynamics hypotension, potassium, haemodialysis, dialysis fluids

\section{Background}

Kidneys are responsible for long-term potassium homeostasis; this exposes patients with end-stage renal disease to a high risk of hyperkalaemia [1-5]. Recovering potassium homeostasis is one of the important objective of dialysis. Considering that its location is mainly intracellular (98\% of the pool [1]), its potential removability during a haemodialysis session is quantitatively modest (between 40 and $80 \mathrm{mmol}$ corresponding to $1-2 \%$ of total body potassium) [6]. As a consequence, even if, in order to be

\footnotetext{
* Correspondence: luca.gabutti@eoc.ch

'Division of Nephrology, Ospedale la Carità, Via Ospedale, 6600 Locarno, Switzerland

Full list of author information is available at the end of the article
}

suitable, potassium removal during dialysis should be equal to the amount accumulated during the inter-dialytic phase, in clinical practice the potassium concentration in the dialysate is usually adjusted with the suboptimal goal of avoiding pre-dialysis hyperkalaemia [7].

The importance of the body content and serum concentration of potassium to control blood pressure remains controversial. Epidemiological data suggest a role for potassium depletion as a co-factor in the development and severity of hypertension, while dietary potassium inversely correlates with blood pressure [8-10]. In animal models, an acute decrease in serum potassium concentration produces vasocostriction mediated by the vascular endothelium and an increase
C Biomed Central

다 2011 Gabutti et al; licensee BioMed Central Ltd. This is an Open Access article distributed under the terms of the Creative Commons Attribution License (http://creativecommons.org/licenses/by/2.0), which permits unrestricted use, distribution, and reproduction in any medium, provided the original work is properly cited. 
in myocardial contractility; the opposite effect is observed if it increases [11,13].

In haemodialysis nephrologists are faced with sudden changes in blood pressure and haemodynamic fragility phases that have a multi-factorial origin; ultrafiltration, decrease in osmolarity with imbalance and correction of metabolic acidosis play a predominant role [7,14-19]. Despite this, and thanks to some strategies based on current practice, with particular reference to calcium and magnesium concentration in the dialysate $[16,20]$, dialysate temperature [21] and ultrafiltration and sodium concentration profiles [7,22-25], pressure stability is guaranteed as a general rule. Some electrolytes, particularly sodium and bicarbonate, can be modulated in profiles with the purpose of better respecting the gap in osmolarity or concentration that is established during the haemodialysis session, but their haemodynamic effect still remains controversial $[21,23,25]$.

Serum potassium is an electrolyte whose concentration - in order to guarantee a negative balance - varies rapidly and significantly during dialysis, frequently resulting in going from pre-dialysis hyperpotassaemia to intra-dialysis hypopotassaemia. In a study performed by Dolson, designed to analyze the consequences of acute potassium changes on haemodynamics, differences in intra-dialytic blood pressure were not found between the groups treated with dialysates containing 1,2 or 3 $\mathrm{mmol} / \mathrm{l}$ of potassium [6]. However, at the end of the dialysis session those patients treated with the lower potassium concentrations showed what was called a "rebound hypertension" [6].

With the purpose of better characterising this phenomenon, we redesigned the study dividing the dialysis session into 3 phases (in fact, clinical practice suggests that the haemodynamic pattern at the beginning, intermediate and final phases of the dialysis are not the same) and programming for each a more or less sharp drop in serum potassium concentration, respecting in the meantime the need to remove the amount of potassium that usually keeps the patient in steady-state. Using a crossover protocol, we divided the dialysis session into 3 tertiles where the potassium concentration in the dialysate was modulated between the usual concentration for the study subject and two cut-off points at $+1 \mathrm{e}-1 \mathrm{mmol} / \mathrm{l}$ respectively. To complete the information provided by blood pressure, haemodynamics were measured in a non-invasive manner using a finger beat-to-beat monitor.

The primary end point was the difference in haemodynamic parameters between the extremes in potassium concentration of the dialysate, while the incidence of hypotension during dialysis was considered a secondary end point.

\section{Methods}

Twenty-four chronic haemodialysis patients (13 male and 11 female) were enrolled in the study. Each patient was dialysed for 3 to 4 hours and 30 minutes three times a week and was clinically stable and without intercurrent illnesses. Using a single blind crossover design, patients were randomised in the six dialysate potassium sequences of the study. Each dialysis session was divided into three equal parts (tertiles): during one part the potassium concentration of the dialysate was the same as the one usually prescribed to the patient, whereas during the other two parts it was either increased or reduced by $1 \mathrm{mmol} / \mathrm{L}$. The 6 different permutations were repeated twice, so that each patient underwent 12 dialysis sessions during the study (see Table 1 for sequence details).

The haemodialyses were performed using a $4008 \mathrm{H}$ machine, equipped with a cartridge of bicarbonate $\mathrm{Bibag}^{\odot}$, and a high flux single use polysulfone membrane, all from Fresenius Medical Care (Bad Homburg, Germany). The prescribed dialyser effective surface area, dialysis fluid conductibility, dialysate temperature and composition (with the exception of potassium concentration), effective blood flow, and dry weight were recorded at the enrolment in the study and were then left unchanged. The medications of the patients were also left unchanged. Serum potassium and patient weight were measured at the beginning and at the end of each dialysis session. Blood samples were taken from the arterial limb of the shunt.

$\mathrm{Kt} / \mathrm{V}$ was used to quantify haemodialysis adequacy and was calculated using a second generation single-pool Daugirdas formula $(\mathrm{Kt} / \mathrm{V}=-\ln (\mathrm{R}-0.03)+[(4-3.5 \times \mathrm{R}) \times$ $(\mathrm{UF} / \mathrm{W})$ ], where $\mathrm{R}=$ post-dialysis $\mathrm{BUN} /$ pre-dialysis $\mathrm{BUN}, \mathrm{UF}=$ net ultrafiltration, $\mathrm{W}=$ weight, $\mathrm{K}=$ dialyzer clearance of urea, $\mathrm{t}=$ dialysis time, and $\mathrm{V}=$ patient's total body water.

The incidence of hypotension episodes (defined as a systolic blood pressure $<90 \mathrm{mmHg}$ ) was recorded.

Table 1 Dialysate potassium sequences

\begin{tabular}{|c|c|c|c|}
\hline \multirow[t]{2}{*}{ Sequence } & \multicolumn{3}{|c|}{ Dialysate Potassium } \\
\hline & 1st tertile & 2nd tertile & 3th tertile \\
\hline 1 & $\mathrm{~K}-1$ & K & $K+1$ \\
\hline 2 & K-1 & $K+1$ & K \\
\hline 3 & K & K-1 & $K+1$ \\
\hline 4 & K & $K+1$ & $\mathrm{~K}-1$ \\
\hline 5 & $K+1$ & K & $\mathrm{K}-1$ \\
\hline 6 & $K+1$ & $\mathrm{~K}-1$ & K \\
\hline
\end{tabular}

Dialysate potassium sequences used in the study. The population was randomised to begin with one of the six sequences. ( $\mathrm{K}=$ usual potassium concentration (range 2 to $4 \mathrm{mmol} / \mathrm{l}), \mathrm{K}+1$ and $\mathrm{K}-1=+$ or $-1 \mathrm{mmol} / \mathrm{L}$ of potassium). 
Systolic and diastolic blood pressures, heart rate, stroke volumes (integrated mean of the flow waveform between the current upstroke and the dicrotic notch) and total peripheral resistances (ratio of mean arterial pressure to stroke volume multiplied by heart rate) were evaluated at the beginning of the session and then every 30 minutes using a Finometer ${ }^{\odot}$ finger beat-to-beat monitor (Finapres Medical Systems BV, Arnhem, The Netherlands). Finometer ${ }^{\odot}$ measures finger blood pressure noninvasively on a beat-to-beat basis and gives waveform measurements similar to intra-arterial recordings.

Mean blood pressure $\left(\mathrm{BP}_{\text {mean }}\right)$ was calculated using the following formula: $\mathrm{BP}_{\text {mean }}=\left(\mathrm{BP}_{\text {syst }}+2 \mathrm{BP}_{\text {dias }}\right) / 3$, where $\mathrm{BP}_{\text {syst }}$ and $\mathrm{BP}_{\text {dias }}$ are systolic and diastolic blood pressure, respectively.

The fluid loss as a function of the time was considered to be constant during the dialysis session and was recorded as total ultrafiltration. The dry weight was established on the basis of clinical assessment and bioimpedance (Body Composition Monitor, Fresenius Medical Care; Bad Homburg, Germany).

Statistical analyses were performed using the SAS System (Statistical Analysis System). Comparisons between body weight, potassium concentration and haemodynamic parameters were done first with an ANOVA followed, if significant by a paired t-test performed between the mean values obtained in each patient with each modality. To improve the probability of showing significant differences, the haemodynamic parameters within the tertiles were compared against the dialysate potassium concentration cut-off points $(-1$ vs. $+1 \mathrm{mmol} /$ 1). Percentages were compared using a Fisher Exact test. In all cases, a $P \leq 0.05$ was considered statistically significant; $P$ was expressed as $n s$ (not significant) or as significant $(P \leq 0.05)$.

The protocol of the study was approved by the local Ethical Committee (Comitato Etico Cantonale del Cantone Ticino). All the patients gave written informed consent prior to enrolling in the study.

\section{Results}

\section{Characteristics of the studied population}

The characteristics of the studied population $(n=24)$ at the moment of enrolment were (mean \pm SD): age $70.3 \pm$ 9.8 years, weight $71.8 \pm 17.2 \mathrm{~kg}$, male/female ratio 1.18 . The basis haemodialyses prescriptions were: dialyser effective surface area $1.79 \pm 0.09 \mathrm{~m}^{2} ; \mathrm{Kt} / \mathrm{V} 1.65 \pm 0.33$; dialysis fluid conductibility $13.8 \mathrm{~ms} / \mathrm{cm}$; dialysis fluid temperature 35.5 to $37.5^{\circ} \mathrm{C}$; effective blood flow $334 \pm$ $69 \mathrm{ml} / \mathrm{min}$; dialysis fluid flow rate 500 to $800 \mathrm{ml} / \mathrm{min}$, potassium 2 to $4 \mathrm{mmol} / \mathrm{l}$, magnesium $0.5 \mathrm{mml} / \mathrm{l}$, calcium 1.25 to $1.50 \mathrm{mmol} / \mathrm{l}$, acetate $3 \mathrm{mmol} / \mathrm{l}$ and glucose $1 \mathrm{~g} / \mathrm{l}$ (see Table 2 for details including underlying nephropathies, comorbidities, antihypertensive drugs in use, dry weight, dialyser surface area, dialysate duration, and $\mathrm{Kt} / \mathrm{V})$.

\section{Serum potassium and ultrafiltration}

The average total ultrafiltration obtained in the 6 sequences of dialysate potassium concentration used for the study did not show any significant differences. Predialysis serum potassium was in turn comparable, while, as expected, post-dialysis serum potassium was influenced mainly by the potassium concentration in the dialysate during the last dialysis tertile, producing significant differences $(p<0.01)$ between the sequences that ended with the usual dialysate potassium concentration, supplemented by 1 or reduced by $1 \mathrm{mmol} / \mathrm{l}$ (Table 3).

\section{Effect of the potassium variations on systemic haemodynamics}

The analysis of the evolution of haemodynamic parameters as a function of dialysis tertiles has not shown any significant differences between the 6 dialysate sequences used during the study (Figures 1, 2, 3 and 4).

If, however, (in post hoc analysis) the mean pressure of the different sequences is taken into account and grouped as a function of dialysate potassium concentration in the first tertile ( 1 with 2,3 with 4 and 5 with 6 ), the differences become significant $(\mathrm{p}<0.01)$. The lowest mean pressure is thus recorded in the sequences that start by inducing the fastest decrease in serum potassium (Table 4).

At the same time, by comparing - as prespecified haemodynamic parameters in the treatments performed with the higher and lower potassium concentration in the dialysate, significant differences in systolic and mean blood pressure and peripheral resistance were found within the tertiles. The systolic and mean blood pressure, as well as peripheral resistance, were lower for the first and second tertiles using the dialysate with the lowest potassium concentration. The stroke volume showed a non-statistically-significant inverse trend. In the last tertile the differences were narrowed, losing significance (see Figure 5, 6, 7 and 8 for details).

\section{Incidence of hypotension episodes}

Hypotension episodes were significantly more numerous in the haemodialysis phases where the lower potassium concentrations were used in the dialysate (Figure 9). During the 288 dialysis performed in the study, 18 hypotension episodes (systolic blood pressure $<90$ $\mathrm{mmHg}$ ) were recorded, $72 \%$ of which occurred in the tertiles with the lower dialysate potassium concentration ( $11 \%$ with the usual concentration and $17 \%$ with the higher concentration). 
Table 2 Characteristics of the cohort

\begin{tabular}{|c|c|c|c|c|c|c|c|c|c|c|c|c|c|}
\hline \multirow{2}{*}{$\begin{array}{l}\text { Patient } \\
\text { number }\end{array}$} & \multirow{2}{*}{$\begin{array}{l}\text { Sex } \\
M / F\end{array}$} & \multirow{2}{*}{$\begin{array}{l}\text { Age } \\
(y)\end{array}$} & \multirow{2}{*}{$\begin{array}{c}\text { Underlying } \\
\text { nephropathy }\end{array}$} & \multicolumn{2}{|c|}{ Comorbidities } & \multicolumn{4}{|c|}{ Medication } & \multirow{2}{*}{$\begin{array}{c}\text { Dry } \\
\text { weight } \\
(\mathbf{k g})\end{array}$} & \multirow{2}{*}{$\begin{array}{l}\text { Dialyser surface } \\
\quad \text { area }(\mathrm{m} 2)\end{array}$} & \multirow{2}{*}{$\begin{array}{c}\text { Dialysis } \\
\text { Duration (h) }\end{array}$} & \multirow{2}{*}{$\begin{array}{c}\mathrm{Kt} / \\
\mathrm{V}\end{array}$} \\
\hline & & & & $\begin{array}{l}\text { Ischemic cardio- } \\
\text { myopathy }\end{array}$ & $\begin{array}{l}\text { Diabetes } \\
\text { mellitus }\end{array}$ & $\begin{array}{c}\text { Beta- } \\
\text { blockers }\end{array}$ & $\begin{array}{c}\text { Calcium } \\
\text { antagonists }\end{array}$ & $\begin{array}{c}\text { Alpha- } \\
\text { blockers }\end{array}$ & $\begin{array}{l}\text { ACE-inhibitors } \\
\text { or ARB }\end{array}$ & & & & \\
\hline 1 & $\mathrm{~F}$ & 75 & Diabetic nephropathy & $Y$ & $Y$ & $\mathrm{Y}$ & $\mathrm{N}$ & Y & Y & 72.5 & 1.8 & 3.0 & 1.51 \\
\hline 2 & $\mathrm{~F}$ & 88 & Diabetic nephropathy & $\mathrm{N}$ & Y & Y & Y & Y & Y & 60.0 & 1.8 & 3.0 & 1.48 \\
\hline 3 & M & 59 & Diabetic nephropathy & Y & Y & Y & N & N & Y & 100.5 & 1.8 & 4.0 & 1.44 \\
\hline 4 & M & 71 & Nephroangiosclerosis & Y & N & Y & N & N & Y & 69.5 & 1.8 & 4.0 & 1.66 \\
\hline 5 & M & 59 & $\begin{array}{l}\text { Focal segmental } \\
\text { glomerulosclerosis }\end{array}$ & N & $\mathrm{N}$ & Y & Y & Y & $\mathrm{N}$ & 79.5 & 1.8 & 3.5 & 1.46 \\
\hline 6 & M & 88 & Nephroangiosclerosis & $\mathrm{N}$ & $\mathrm{N}$ & Y & N & $\mathrm{N}$ & $\mathrm{N}$ & 76.0 & 1.4 & 4.0 & 1.52 \\
\hline 7 & $\mathrm{~F}$ & 86 & Nephroangiosclerosis & Y & $\mathrm{N}$ & Y & N & N & Y & 43.0 & 1.8 & 3.0 & 1.59 \\
\hline 8 & M & 81 & Nephroangiosclerosis & $\mathrm{N}$ & $\mathrm{N}$ & Y & Y & $\mathrm{N}$ & $\mathrm{N}$ & 79.0 & 1.8 & 3.5 & 1.38 \\
\hline 9 & $\mathrm{~F}$ & 74 & Diabetic nephropathy & $\mathrm{N}$ & Y & $\mathrm{N}$ & Y & $\mathrm{N}$ & $\mathrm{N}$ & 81.0 & 1.8 & 3.5 & 1.76 \\
\hline 10 & M & 64 & Nephroangiosclerosis & $\mathrm{N}$ & N & Y & N & $\mathrm{N}$ & N & 98.0 & 1.8 & 3.5 & 1.41 \\
\hline 11 & M & 74 & Nephroangiosclerosis & N & $\mathrm{N}$ & N & N & $\mathrm{N}$ & N & 69.5 & 1.8 & 4.0 & 1.52 \\
\hline 12 & $\mathrm{~F}$ & 66 & $\begin{array}{c}\text { Trombotic } \\
\text { microangiopathy }\end{array}$ & $\mathrm{N}$ & $\mathrm{N}$ & $\mathrm{N}$ & Y & $\mathrm{N}$ & Y & 52.0 & 1.8 & 3.5 & 1.90 \\
\hline 13 & M & 65 & $\begin{array}{l}\text { Focal segmental } \\
\text { glomerulosclerosis }\end{array}$ & $\mathrm{N}$ & N & Y & N & $\mathrm{N}$ & $\mathrm{N}$ & 87.2 & 1.8 & 4.0 & 2.08 \\
\hline 14 & M & 72 & Nephroangiosclerosis & Y & $\mathrm{N}$ & $\mathrm{N}$ & $\mathrm{N}$ & $\mathrm{N}$ & Y & 92.0 & 1.8 & 3.0 & 1.00 \\
\hline 15 & $\mathrm{~F}$ & 75 & Diabetic nephropathy & N & Y & Y & Y & Y & Y & 48.0 & 1.8 & 3.5 & 1.56 \\
\hline 16 & M & 77 & $\begin{array}{c}\text { Proliferative } \\
\text { glomerulonephritis }\end{array}$ & Y & N & Y & N & N & Y & 80.5 & 1.8 & 3.0 & 1.07 \\
\hline 17 & M & 72 & Diabetic nephropathy & Y & Y & $\mathrm{N}$ & $\mathrm{N}$ & $\mathrm{N}$ & Y & 89.5 & 1.8 & 4.0 & 1.37 \\
\hline 18 & $\mathrm{~F}$ & 65 & Diabetic nephropathy & Y & Y & Y & Y & Y & Y & 48.0 & 1.8 & 3.5 & 2.08 \\
\hline 19 & $\mathrm{~F}$ & 56 & Nephroangiosclerosis & $\mathrm{N}$ & N & Y & Y & $\mathrm{N}$ & Y & 65.0 & 1.8 & 3.5 & 2.07 \\
\hline 20 & $\mathrm{~F}$ & 48 & IgA nephropathy & $\mathrm{N}$ & Y & Y & N & $\mathrm{N}$ & $\mathrm{N}$ & 60.0 & 1.8 & 3.5 & 2.20 \\
\hline 21 & $\mathrm{~F}$ & 70 & Nephroangiosclerosis & $\mathrm{N}$ & $\mathrm{N}$ & $\mathrm{N}$ & Y & $\mathrm{N}$ & Y & 47.5 & 1.8 & 3.5 & 2.00 \\
\hline 22 & $\mathrm{~F}$ & 64 & $\begin{array}{l}\text { Relapsing } \\
\text { pyelonephritis }\end{array}$ & $\mathrm{N}$ & $\mathrm{N}$ & Y & Y & Y & Y & 55.0 & 1.8 & 3.3 & 2.22 \\
\hline 23 & M & 68 & IgA nephropathy & Y & $\mathrm{N}$ & $\mathrm{N}$ & Y & $\mathrm{N}$ & $\mathrm{N}$ & 94.5 & 1.8 & 4.0 & 1.52 \\
\hline 24 & M & 71 & Nephroangiosclerosis & Y & Y & Y & N & $\mathrm{N}$ & $\mathrm{N}$ & 75.5 & 1.8 & 4.5 & 1.70 \\
\hline
\end{tabular}

Characteristics of the population at the beginning of the study. ( $M$, male; $F$, female; $Y$, yes; $N$, no; ACE, angiotensin converting enzyme; ARB, angiotensin receptor antagonists). 
Table 3 Serum potassium and ultrafiltration

\begin{tabular}{|c|c|c|c|c|c|c|c|c|}
\hline Sequence & $\begin{array}{l}\text { Ultrafiltration } \\
\text { (L) }\end{array}$ & SD & $\begin{array}{c}\text { Serum K pre-dialysis } \\
(\mathrm{mmol} / \mathrm{L})\end{array}$ & SD & $\begin{array}{c}\text { Serum K post- } \\
\text { dialysis } \\
\text { (mmol/L) }\end{array}$ & SD & $\begin{array}{c}\text { pre-post dialysis } \\
\text { delta K } \\
\text { (mmol/L) }\end{array}$ & SD \\
\hline 1 & 1.68 & 0.99 & 4.65 & 0.77 & 3.90 & 0.32 & 0.83 & 1.02 \\
\hline 2 & 1.61 & 0.94 & 4.77 & 0.66 & 3.74 & 0.46 & 1.03 & 0.85 \\
\hline 3 & 1.54 & 0.95 & 4.92 & 0.71 & 3.93 & 0.32 & 1.05 & 1.02 \\
\hline 4 & 1.64 & 0.94 & 4.84 & 0.84 & 3.46 & 0.34 & 1.38 & 0.95 \\
\hline 5 & 1.51 & 0.82 & 4.74 & 0.69 & 3.39 & 0.51 & 1.31 & 1.58 \\
\hline 6 & 1.64 & 1.08 & 4.81 & 0.70 & 3.73 & 0.34 & 1.11 & 0.84 \\
\hline
\end{tabular}

Serum Potassium pre- and post-dialysis and mean total ultrafiltration as a function of the dialysate sequences. Between the pairs of sequences 1 and 3,2 and 6 and 4 and 5 , the difference in the mean post-dialysis serum potassium concentration was significant $(p<0.01)$.

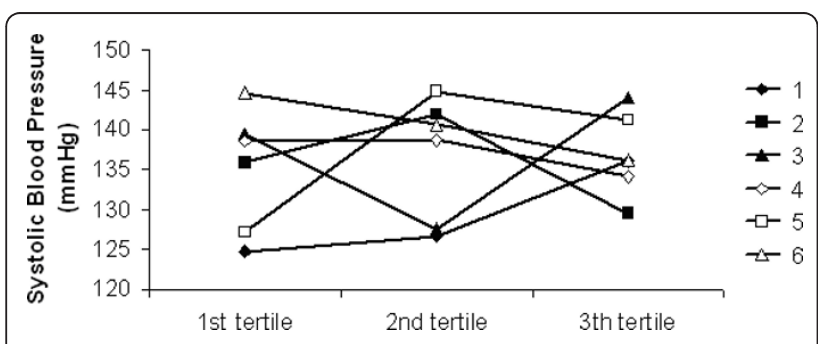

Figure 1 Systolic blood pressure. Systolic blood pressure as a function of the dialysis tertiles in the 6 dialysate sequences (1 to 6).

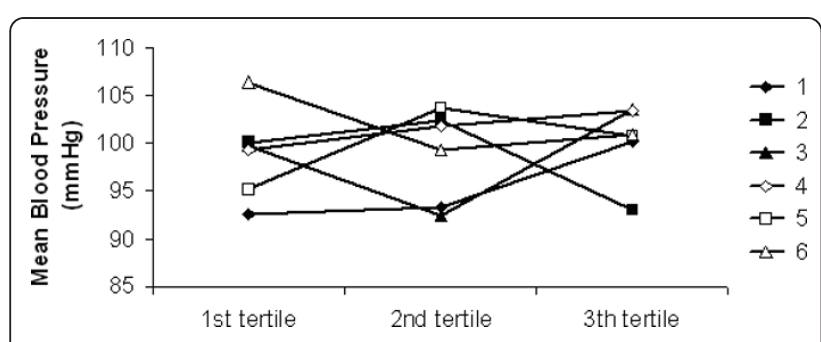

Figure 2 Mean blood pressure. Mean blood pressure as a function of the dialysis tertiles in the 6 dialysate sequences (1 to 6).

\section{Discussion}

The study showed that a low potassium concentration in the dialysate, inducing a rapid decrease in serum potassium, causes a decrease in systolic and mean blood pressure correlated with a decrease in peripheral resistance. The decrease in pressure recorded when a dialysate with a potassium concentration $1 \mathrm{mmol} / \mathrm{l}$ lower than the one usually employed for the patient was used, translated into a higher incidence of hypotension, defined as episodes with systolic blood pressure $<90$ $\mathrm{mmHg}$ ( $72 \%$ of the episodes happened during the tertile using the lowest dialysate potassium concentration). The dialysate potassium concentration in the initial tertile affects mean blood pressure for the whole dialysis session in that a larger gap between serum and dialysate potassium concentrations results in a lower pressure. The effect of removing potassium is progressively

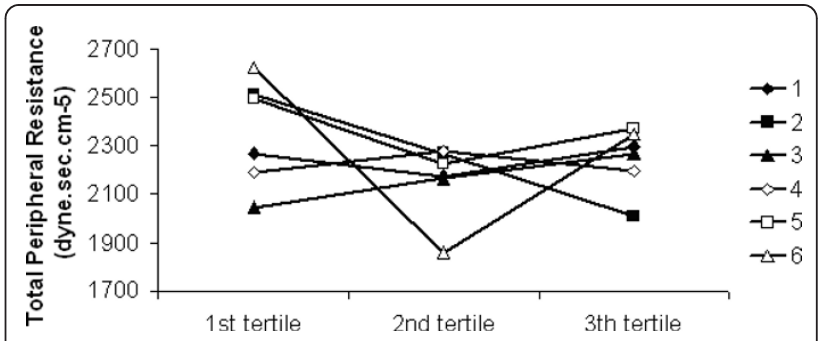

Figure 3 Peripheral resistance. Total peripheral resistance as a function of the dialysis tertiles in the 6 dialysate sequences ( 1 to 6 ).

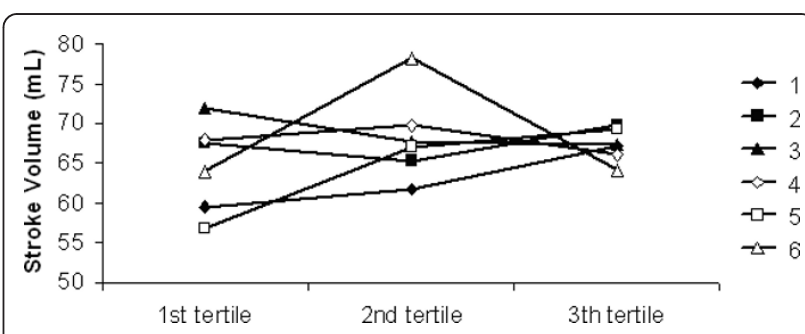

Figure 4 Stroke volume. Stroke volume as a function of the dialysis tertiles in the 6 dialysate sequences ( 1 to 6 ).

reduced during dialysis, with haemodynamic consequences that are no longer significant during the final tertile. The lesser impact during the intermediate and final stages of dialysis could be due to the gap between serum and dialysate potassium, which progressively narrows during the dialysis session.

The data obtained agree with what was observed by Dolson [6] who, while not highlighting pressure discrepancies during the dialysis using dialysates with potassium concentrations of 1,2 or $3 \mathrm{mmol} / \mathrm{l}$, had observed hypertension, defined as "reflex" (or "rebound"), at the end of the session that used the two lower potassium concentrations. The lack of differences during dialysis in the aforementioned study could have been a consequence of (i) the lower statistical power (11 versus 24 subjects investigated) and (ii) the different method used (based on the steady state prescription, we randomly reduced and increased the dialysate potassium concentration in the 
Table 4 Mean haemodynamic parameters

\begin{tabular}{ccccccccc}
\hline Sequence & $\begin{array}{c}\text { Systolic BP } \\
(\mathbf{m m H g})\end{array}$ & $\begin{array}{c}\text { SD } \\
(\mathbf{m m H g})\end{array}$ & $\begin{array}{c}\text { Mean BP } \\
(\mathbf{m m H g})\end{array}$ & $\begin{array}{c}\text { SD } \\
(\mathbf{m m H g})\end{array}$ & $\begin{array}{c}\text { TPR } \\
(\text { dyne.sec.cm-5) }\end{array}$ & $\begin{array}{c}\text { SD } \\
(\text { dyne.sec.cm-5) }\end{array}$ & $\begin{array}{c}\text { Stroke volume } \\
(\mathbf{m L})\end{array}$ & $\begin{array}{c}\text { SD } \\
(\mathbf{m L})\end{array}$ \\
\hline $\mathbf{1}$ & 129.1 & 19.9 & 95.4 & 12.7 & 2249 & 898 & 62.9 \\
$\mathbf{2}$ & 135.8 & 18.0 & 98.5 & 10.5 & 2262 & 1143 & 23.0 \\
$\mathbf{3}$ & 137.0 & 20.6 & 98.6 & 13.6 & 2160 & 1134 & 67.5 \\
$\mathbf{4}$ & 137.1 & 19.2 & 101.5 & 12.2 & 2221 & 1010 & 69.0 \\
$\mathbf{5}$ & 137.7 & 21.2 & 99.9 & 12.5 & 2366 & 905 & 67.9 \\
$\mathbf{6}$ & 140.5 & 16.4 & 102.3 & 12.0 & 2277 & 1202 & 64.4 \\
\hline
\end{tabular}

Mean values of systolic and mean blood pressure (BP), total peripheral resistance (TPR) and stroke volume for the 3 dialysis tertiles.

whole group). The cited blood pressure rebound after dialysis suggests a counterregulatory phenomenon compatible with an undetected intradialytic hypotension/ hypoperfusion phase.

However, if we take into account the experimental data obtained from animals besides the typical metabolic circumstances of kidney failure that requires dialysis, it is surprising to observe the haemodynamic pattern that is traced and which, contrary to expectations, shows a hypertensive effect for acute decrease in serum potassium. In fact, the experimental hypokalaemia model demonstrates a vasoconstriction and an increase in myocardial contractility [11-13]. The difference between the theoretical and the observed pattern could be due to the method employed to evaluate peripheral resistance (indirect, non-invasive measurements using beat-to-beat in our case) and the metabolic circumstances of dialysis with sharp variations in other factors that together can modify haemodynamics (calcaemia, osmolarity, acid-base balance, temperature), as well as concomitant counterregulatory phenomena, particularly the sympathetic and renin-angiotensin systems. The fact that hypokalaemia sensitizes myocardium to hypoxic related dysfunction [26] together with the selection for the study of an elderly population (mean age 70.3 years) with a high incidence of ischemic cardiomyopathy (10 out of 24

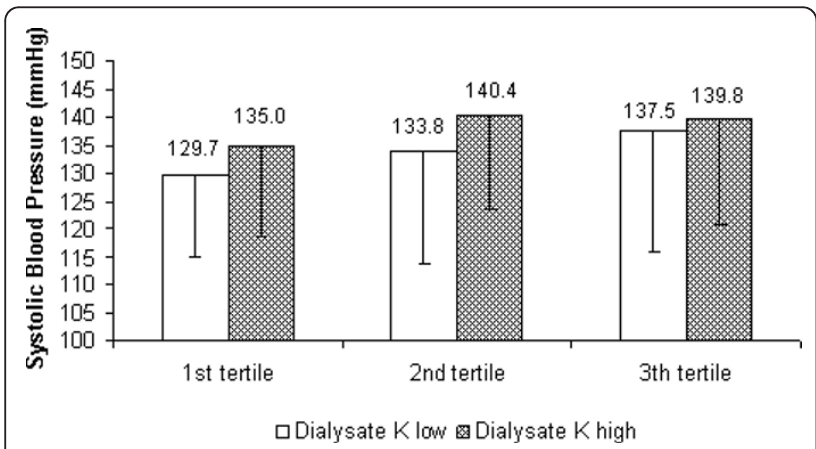

Figure 5 Systolic blood pressure. Systolic blood pressure as a function of dialysis tertiles comparing treatments with the two potassium $(K)$ concentration cut-off points in the dialysate (high $=\mathrm{K}$ +1 and low $=K-1)$. P for the 1st, 2nd and 3rd tertiles: $<0.05,<0.05$ and ns respectively. subjects) could have influenced the incidence of intradialytic hypotensions and the results. Moreover two other reasons could potentially explain a blood pressure reduction related to acute potassium decrease in the dialysis population: hypokalaemia may exacerbate autonomic dysfunction while intra-dialytic potassium loss accounts for a decrease in total osmoles [7].

Regardless of the pathophysiological explanations of the haemodynamic consequences, the results are potentially relevant in that (i) dialysate potassium concentration could theoretically be modulable in a profile, as proposed for other electrolytes like sodium and bicarbonate and (ii) more attention could be paid to controlling the potassium balance with alternative measures (diet, chelating agents, avoidance of medications which inhibits the renin-angiotensin system if unnecessary [27] and possibly prescription of mineralocorticoids [28]).

\section{Conclusions}

In conclusion, a rapid decrease in the concentration of serum potassium during the initial stage of the dialysis obtained by reducing the concentration of potassium in the dialysate - translates into a decrease of systolic and mean blood pressure mediated by a decrease in peripheral resistance. The risk of intra-dialysis hypotension inversely correlates to the potassium concentration in

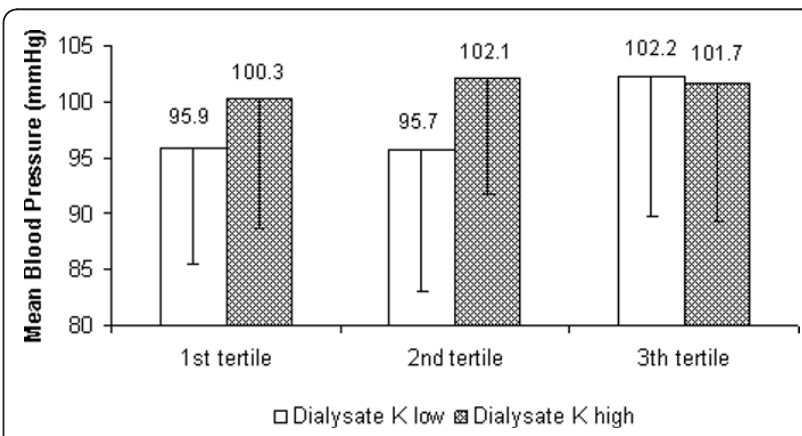

Figure 6 Mean blood pressure. Mean blood pressure as a function of dialysis tertiles comparing treatments with the two potassium $(\mathrm{K})$ concentration cut-off points in the dialysate (high $=\mathrm{K}$ +1 and low $=K-1$ ). P for the 1st, 2nd and 3rd tertiles: $<0.01,<0.01$ and ns respectively. 


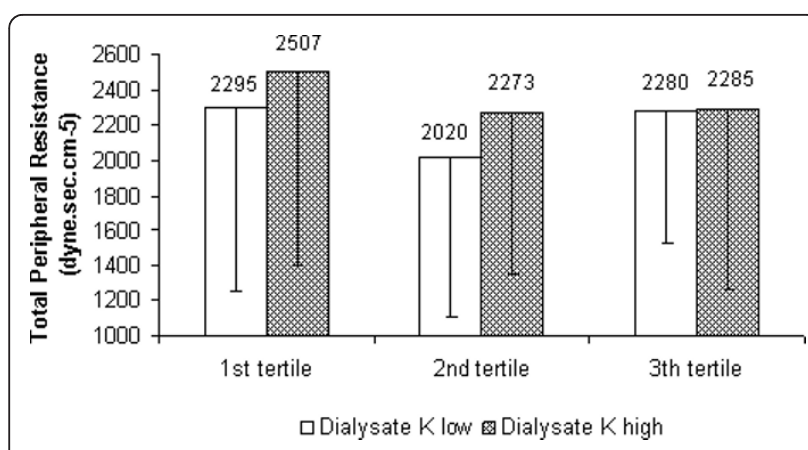

Figure 7 Total peripheral resistance. Total peripheral resistance as a function of dialysis tertiles comparing treatments with the two potassium $(K)$ concentration cut-off points in the dialysate (high $=\mathrm{K}$ +1 and low $=K-1)$. P for the 1st, 2nd and 3rd tertiles: $<0.05,<0.05$ and $\mathrm{ns}$ respectively.

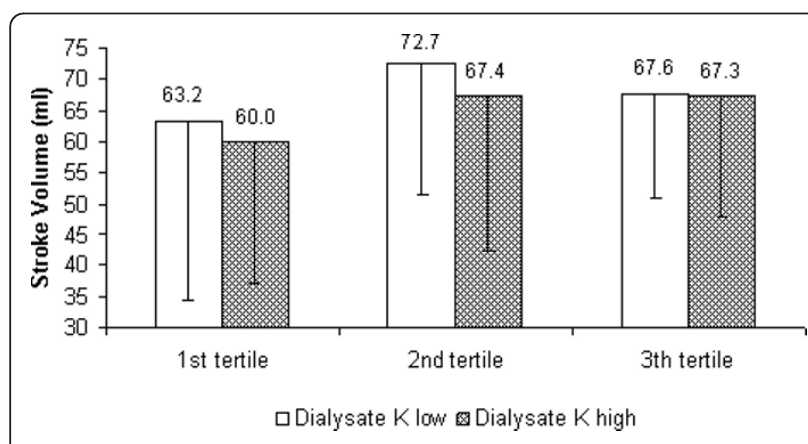

Figure 8 Stroke volume. Stroke volume as a function of dialysis tertiles comparing treatments with the two potassium $(\mathrm{K})$ concentration cut-off points in the dialysate (high $=\mathrm{K}+1$ and low $=$ K-1). P for the 1st, 2nd and 3rd tertiles: ns.

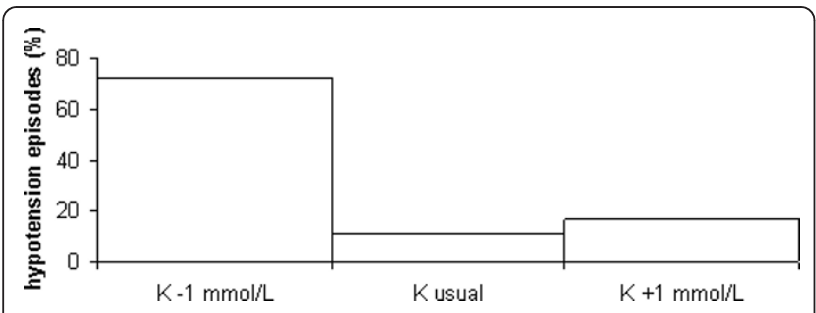

Figure 9 Incidence of hypotension episodes. Incidence of hypotension episodes as a function of the dialysate potassium (K) concentration. $\mathrm{P}$ for the differences between both $\mathrm{K}-1$ and $\mathrm{K}$ and $\mathrm{K}$ 1 and $\mathrm{K}+1<0.01 ; \mathrm{n}=18$.

the dialysate. Based on the results obtained by this study, modulating potassium concentration in the dialysate during haemodyalisis sessions could have favourable haemodynamic consequences.

\section{Acknowledgements}

This work was funded by a grant from the Fondazione Ettore Balli, Locarno, Switzerland. The study sponsors played no role in study design, data collection, data analysis, data interpretation, or in the writing of the report.

\section{Author details}

'Division of Nephrology, Ospedale la Carità, Via Ospedale, 6600 Locarno, Switzerland. ${ }^{2}$ Department of Internal Medicine, Ospedale la Carità, Locarno, Switzerland. ${ }^{3}$ Division of Nephrology, University Hospital of Lausanne, Lausanne, Switzerland.

\section{Authors' contributions}

LG was involved in the study design, sample collection, analysis and interpretation of the data and in the writing of the report; IS, BL and DS participated in the sample collection, analysis and interpretation of the data and in the writing of the paper, MB helped formulate the study design, the data analysis strategy and contributed to the writing of the paper. Al authors have read and approved the final version of the manuscript.

\section{Competing interests}

The authors declare that they have no competing interests.

Received: 19 October 2010 Accepted: 6 April 2011

Published: 6 April 2011

\section{References}

1. Rastegar A, Soleimani M: Hypokalaemia and hyperkalaemia. Postgrad Med J 2001, 77:759-764, PMID: 11723313

2. Bia MJ, DeFrontzo RA: Extrarenal potassium homeostasis. Am J Physiol 1981, 240:257-268, PMID: 6111930.

3. Fernandez J, Oster JR, Perez GO: Impaired extrarenal disposal of an acute oral potassium load in patients with end-stage renal disease on chronic hemodialysis. Miner Electrolyte Metab 1986, 12:125-129, PMID: 3960016.

4. Perez GO, Pelleya R, Oster JR, Kem DC, Vaamonde CA: Blunted kaliuresis after an acute potassium load in patients with chronic renal failure. Kidney Int 1983, 24:656-662, PMID: 6663988.

5. Musso CG: Potassium metabolism in patients with chronic kidney disease. Part II: patients on dialysis (stage 5). Int Urol Nephrol 2004, 36:469-472, PMID: 15783126

6. Dolson GM, Ellis KJ, Bernardo MV, Prakash R, Adrogué HJ: Acute decreases in serum potassium augment blood pressure. Am J Kidney Dis 1995, 26:321-326, PMID: 7645536

7. Locatelli F, Covic A, Chazot C, Leunissen K, Luño J, Yaqoob M: Optimal composition of the dialysate, with emphasis on its influence on blood pressure. Nephrol Dial Transplant 2004, 19:785-796, PMID: 15031331.

8. Morris RC Jr, Sebastian A, Forman A, Tanaka M, Schmidlin O: Normotensive salt sensitivity: effects of race and dietary potassium. Hypertension 1999, 33:18-23, PMID: 9931076.

9. Stamler J, Rose G, Elliott P, Dyer A, Marmot M, Kesteloot H, Stamler R: Findings of the International Cooperative INTERSALT Study. Hypertension 1991, 17:19-15, PMID: 1987018.

10. Whelton PK, He J, Cutler JA, et al: Effects of oral potassium on blood pressure: meta-analysis of randomized controlled clinical trials. JAMA 1997, 277:1624-1632, PMID: 9168293.

11. Amberg GC, Bonev AD, Rossow CF, Nelson MT, Santana LF: Modulation of the molecular composition of large conductance, $\mathrm{Ca}^{2+}$ activated $\mathrm{K}^{+}$ channels in vascular smooth muscle during hypertension. J Clin Invest 2003, 112:717-724, PMID: 12952920

12. Haddy FJ, Vanhoutte PM, Feletou M: Role of potassium in regulating blood flow and blood pressure. Am J Physiol Regul Integr Comp Physiol 2006, 290:546-552, PMID: 16467502

13. Prasad K, Koob R: Cardiovascular function in dogs with acute hypokalemia. Angiology 1978, 29:589-600, PMID: 686495.

14. Rodrigo F, Shideman J, McHugh R, Buselmeier T, Kjellstrand C: Osmolality changes during hemodialysis. Natural history, clinical correlations, and influence of dialysate glucose and intravenous mannitol. Ann Intern Med 1977, 86:554-561, PMID: 851303.

15. Van der Sande FM, Kooman JP, Leunissen KM: Intradialytic hypotensionnew concepts on an old problem. Nephrol Dial Transplant 2000, 15:1746-1748, PMID: 11071958.

16. Gabutti L, Bianchi G, Soldini D, Marone C, Burnier M: Haemodynamic consequences of changing bicarbonate and calcium concentrations in haemodialysis fluids. Nephrol Dial Transplant 2009, 24:973-981, PMID: 18842671. 
17. Gabutti L, Ferrari N, Giudici G, Mombelli G, Marone C: Unexpected haemodynamic instability associated with standard bicarbonate haemodialysis. Nephrol Dial Transplant 2003, 18:2369-2376, PMID: 14551368.

18. Sułowicz W, Radziszewski A: Dialysis induced hypotension-a serious clinical problem in renal replacement therapy. Med Pregl 2007, 60:14-20, PMID: 18928150

19. Leunissen KM, Kooman JP, van Kuijk W, van der Sande F, Luik AJ, van Hooff JP: Preventing haemodynamic instability in patients at risk for intra-dialytic hypotension. Nephrol Dial Transplant 1996, 11:11-15, PMID: 8803987.

20. Kyriazis J, Kalogeropoulou K, Bilirakis L, Smirnioudis N, Pikounis V, Stamatiadis D, Liolia E: Dialysate magnesium level and bood pressure. Kidney Int 2004, 66:1221-1231, PMID:15327421.

21. Selby NM, Mclntyre CW: A systematic review of the clinical effects of reducing dialysate fluid temperature. Nephrol Dial Transplant 2006, 21:1883-1898, PMID: 16601075.

22. Van Kuijk WH, Wirtz JJ, Grave W, de Heer F, Menheere PP, van Hooff JP, Leunissen KM: Vascular reactivity during combined ultrafiltrationhaemodialysis: influence of dialysate sodium. Nephrol Dial Transplant 1996, 11:323-328, PMID: 8671787.

23. Kim MJ, Song J, Kim G, Lim H, Lee S: Optimization of dialysate sodium in sodium profiling haemodialysis. Nephrology (Carlton) 2003, 8:S16-22, PMID: 15012686.

24. Stefanidis I, Stiller S, Ikonomov V, Mann H: Sodium and body fluid homeostasis in profiling hemodialysis treatment. Int J Artif Organs 2002, 25:421-428, PMID: 12074340.

25. Stiller S, Bonnie-Schorn E, Grassmann A, Uhlenbusch-Körwer I, Mann H: A critical review of sodium profiling for hemodialysis. Semin Dial 2001 14:337-347, PMID: 11679103.

26. shapiro Jl, Banerjee A, Reiss OK, Elkins N: Acute and chronic hypokalemia sensitize the isolated heart to hypoxic injury. Am J Physiol 1998, 274:1598-1604, PMID:9612369.

27. Knoll GA, Sahgal A, Nair RC, Graham J, Van Walraven C, Burns KD: Reninangiotensin system blockade and the risk of hyperkalemia in chronic hemodialysis patients. Am J Med 2002, 112:110-114, PMID:11835948.

28. Furuya $R$, Kumagai $H$, Sakao T, Maruyama $Y$, Hishida A: Potassium-lowering effect of mineralocorticoid therapy in patients undergoing hemodialysis. Nephron 2002, 92:576-581, PMID:12372940.

\section{Pre-publication history}

The pre-publication history for this paper can be accessed here: http://www.biomedcentral.com/1471-2369/12/14/prepub

doi:10.1186/1471-2369-12-14

Cite this article as: Gabutti et al: Haemodynamic consequences of changing potassium concentrations in haemodialysis fluids. BMC Nephrology 2011 12:14.

\section{Submit your next manuscript to BioMed Central and take full advantage of:}

- Convenient online submission

- Thorough peer review

- No space constraints or color figure charges

- Immediate publication on acceptance

- Inclusion in PubMed, CAS, Scopus and Google Scholar

- Research which is freely available for redistribution

Submit your manuscript at www.biomedcentral.com/submit
Biomed Central 